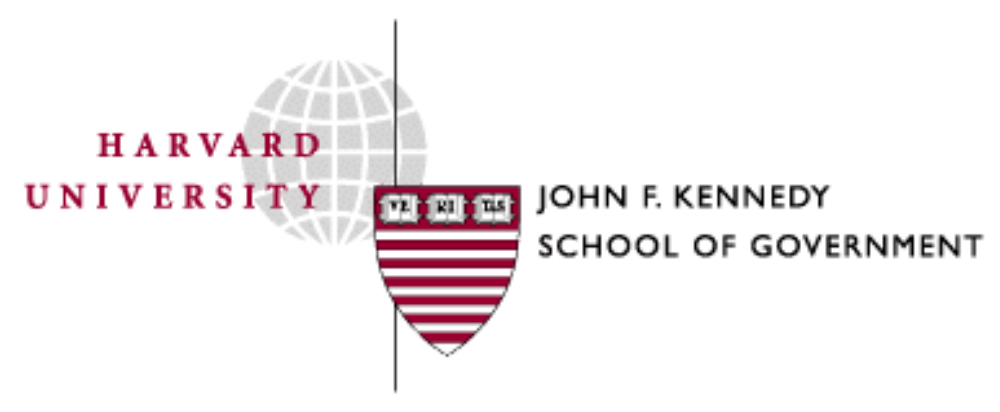

Faculty Research Working Papers Series

Moving Voters in the 2000 Presidential Campaign: Local Visits, Local Media David King and David Morehouse

January 2004

RWP04-003

The views expressed in the KSG Faculty Research Working Paper Series are those of the author(s) and do not necessarily reflect those of the John F. Kennedy School of Government or Harvard University. Copyright belongs to the author(s). Papers may be downloaded for personal use only. 


\section{Moving Voters in the 2000 Presidential Campaign: Local Visits, Local Media ${ }^{1}$}

\author{
David C. King, \\ David Morehouse $^{2}$
}

\section{Harvard University, John F. Kennedy \\ School of Government}

January 14, 2004

Running for office. That phrase, with an emphasis on the word "running," conjures for us memories of candidates darting among cities in the closing days of a campaign, of klieg lights on tarmacs, of caffeinated staffers and the tangible yearning among candidates to have their voices heard, to connect with voters, and to be a hundred places and on a million minds simultaneously.

Candidates want to reach potential voters, but more than reaching voters, they want to move them. This difference between reaching potential voters and actually moving voters to be supporters is crucial in campaigns, and it is at the heart of our proposition in this chapter: there is a poorlyunderstood tradeoff between spending money on television commercials and having candidates make campaign appearances.

Local campaign appearances generate tremendous free local media

\footnotetext{
${ }^{1}$ Forthcoming in David Schultz, ed., Lights, Camera, Campaign, (New York: Peter Lange, 2004).

${ }^{2}$ David C. King is Associate Professor of Public Policy and David Morehouse is Deputy Director of Executive Programs, both at Harvard University's John F. Kennedy School of Government. We thank Secretary Dan Glickman and Catherine McLaughlin, both of the Institute of Politics, for supporting this research. We also thank Peter Buttigieg, Greg Dorchak, Amanda Fuchs, Harrison Hickman, Charles Franklin, Ken Goldstein, Paul Resnick, Eric Rosenbach, and David Schultz.
}

coverage, which often offset the "costs" of appearing before relatively small audiences in out-of-the-way parts of America. Indeed, in many instances, local campaign appearances likely "move" the vote more than higher priced advertisements.

Running candidates from place to place and running commercials in various places are mainstays of presidential campaigns. We expect, though, that on a dollars per vote basis, candidate trips to key regions are very often a more effective way to move voters than blanketing an area with television advertisements. This chapter explores the effects of Vice President Gore's August 2000 Mississippi River Trip on moving voter preferences. With a working knowledge of the Gore campaign in particular (one of the authors was a senior advisor and trip director for Vice President Gore), we share new data about the impact of local visits on local polls of likely voters.

A candidate's time is the most precious commodity in presidential campaigns. Money, the fruit of an investment of personal time by candidates, makes it possible for campaigns to use television, radio, print, the Internet, and personal visits. The goal, naturally, is to reach as many voters as possible with a persuasive message or image, then move them to vote for the candidate, and to do so in the most cost effective ways. The Gore campaign spent $\$ 44.6$ million on television ads and media consulting services from September through November 2000. Over the same period, $\$ 10.7$ million went to travel expenses, including - among other things costs for airplanes, hotels, event equipment and decorations. Over those critical months, $\$ 4.14$ was spent on television for every $\$ 1.00$ spent on campaign visits.

Is that ratio, 4.14 to 1 , even close to being an optimal tradeoff between running commercials and running the candidate? In precise terms, that is an unanswerable question without a randomized controlgroup experiment, but in general terms, we 
can make headway in understanding how to assess the tradeoff. Recent work by Alan Gerber, Don Green and David Nickerson at Yale University gives us an indication for how much money it takes to increase voter turnout. (Which is not the same as turning out a voter for a specific candidate.) Using experiments in which potential voters were randomly assigned to control and treatment groups, the Yale studies estimate that doorto-door visits by campaigns cost from $\$ 12$ to $\$ 20$ per vote, as do phone banks run by volunteers. Professionally run phone banks mobilize relatively few voters and cost $\$ 140$ to $\$ 150$ per vote, which is far more costly than direct mail, at $\$ 40$ per vote (Gerber \& Green 2003, 2001a, 2001b, 2000a, 2000b; Gerber, Green \& Nickerson 2003). In a similar set of experiments focusing on a partisan turnout campaign for Michigan Governor Jennifer Granholm in 2002, Friedrichs (2003) found slightly lower costs per vote, but his analysis confirms the futility of relying so heavily, as most presidential campaigns do, on paid phone banks.

The Yale studies have important lessons for presidential campaigns. Candidates will want to avoid costineffective techniques, such as paid phone banks. Yet in the 2000 campaign and again in the 2004 Democratic primaries, these phone banks were used in record numbers. The distinction that campaigns need to make, once again, is between reaching voters and moving them. Phone calls reach but do not move many voters. Television advertisements may well reach voters, if they are not channel-surfing during commercials, but the advertisements may not move many voters from the "undecided" column. Indeed, voters have become more skeptical of the charges and claims made in campaign ads, and in highly competitive races, viewers may quickly reach a saturation point (Just et al, 1996). Ken Goldstein and his colleagues tracked an astonishing 302,450 presidential spots for in the 2000 campaign (Goldstein 2004).

The Bush and Gore campaigns made thousands of strategic choices about allocating both time and money between candidate visits and television advertising buys. Scholarly literature on this fall in two groups - one focusing primarily on local visits (Holbrook 2002, 1996, Campbell 2000, Shaw 1999b, Jones 1998), and the other largely examining the impact of television ads (Shaw 1999a, Freedman \& Goldstein 1999, Ansolabehere \& Iyengar 1995, Finkel 1993). Both candidate visits and television advertisements certainly have an important impact on votes, but the relative impacts are difficult to gauge. There is no clear causal arrow running from visits to votes or from TV ads to votes. Indeed, voters need to be in some sense predisposed to a candidate for a visit to have an impact (Vavreck, Spiliotes \& Fowler 2002) just as television ads have an impact that depends largely on a viewer's ideology and party identification (Joslyn \& Ceccoli 1996).

\section{Candidate visits have direct and} indirect effects on voters. Some are personally persuaded by a candidate (the direct effect). Many more voters in an area that has been recently been visited by a candidate, however, are moved by the local media coverage of candidate visits. Campaign visits can have very large multiplier effects through local media outlets. Television, especially, reaches voters, but the free local media generated by candidate visits are especially valuable and are likely to have been underappreciated by campaigns.

\section{Local Media}

In July of 2000, the Gore campaign began discussions on campaign tactics and how to best generate energy and positive press coverage leading into and out of the Democratic Convention. Previous 
Democratic Presidential campaigns had used thematic trips with creative modes of transportation to great effect in generating positive local and national press coverage and energizing the base. For example, in 1992, the Clinton/Gore campaign left New York, site of the 1992 Democratic Convention, in a bus caravan across New York, Pennsylvania, and West Virginia. They subsequently had bus trips in the Lake Erie Region, Texas, Georgia, and North Carolina. These were designed to go through battle ground states and hit both small towns and large media markets, while conveying a sense of connectedness with everyday Americans. The rolling bus trips became a campaign metaphor for the Clinton campaign and were credited with playing a pivotal role in Clinton's upset win over the incumbent George Bush.

Local newspapers and television stations are eager to cover campaign events, and they tend to approach politics with less cynicism than one finds among the national press corps. Candidates covered by local media outlets generate sustained stories, often crossing several news cycles. Furthermore, voters pay closer attention to local television news than they do to national news coverage of campaigns.

A Pew Research Center survey, conducted in the wake of the 2002 off-year elections, reported on 2,745 respondents who were asked, "Did you get most of your news about the election campaigns from network TV news, from local TV news, or from cable news networks such as $\mathrm{CNN}$ or MSNBC?" Local television news came in first, with 35 percent, followed by newspapers, cable television and radio at 33 , 21 and 13 percent, respectively. Just 7 percent reported getting most of their campaign news from network television stations (Pew 2003).

Local media coverage, one should hasten to add, is free. And while many viewers now channel surf during political commercials, viewers are more likely to stay tuned while local television news stories replete with video of the high school marching band - are running. And a candidate's interview with a trusted local columnist or news anchor is often more compelling than an Associated Press story by a remote reporter in Texas or Tennessee.

In 1996, the Clinton/Gore campaign, trying to replicate some of the campaign magic from the 1992 campaign, decided to use a train instead of a bus to travel to Chicago for the Convention. The train started in Huntington, West Virginia and traveled on a whistle stop tour through Ohio, Kentucky, and Illinois on it's way to the convention. This trip also managed to create energy, mobilize supporters, generate positive local press coverage, and provide a novelty for the national media.

Part of the geographic strategy of both of these trips was not only to travel through targeted states, but to stop in $2^{\text {nd }}$ and $3^{\text {rd }}$ tier cities and towns that were within reasonable proximity to larger media market hubs, and preferably multi-media markets. This strategy allowed the campaign to go into crucial swing areas that do not normally get many presidential candidate visits. These towns often provided a more Americanaoriented backdrop for the candidate and a friendlier audience.

\section{Consider President Clinton's} February 19, 1993 stop in Chillicothe, Ohio, a town of 23,000 located an hour and a half south of Columbus. The local media covered an event at which more than half of the town showed up, and television stations from Columbus and Dayton sent news crews to cover the visit. President Clinton returned to Chillicothe on August 25, 1996 for a campaign appearance that generated tremendous local news coverage. As Chaz Osburn, managing editor for the Chillicote Gazette explained to other editors in the Gannet Newspaper chain (News Watch, 2000): 
President Clinton's stop in Chillicothe was significant for two reasons. First, he $i s$ the president. But even more interesting was that Clinton had come to Chillicothe 42 months earlier, in February 1993, to conduct his first town meeting as president. So his 90minute stop here on Aug. 25 was, in a way, a homecoming of sorts.

We were tipped off by Bob Gabordi, whose staff was well into covering plans for the whistlestop, to the possibility of a visit. The dog days of summer came crashing to a halt with that call: every available reporter was reassigned to nail down the story.

As it turned out, Clinton's visit was lead story material for nine days. Once the stop was confirmed, we ran a box asking people what question they would ask Clinton if they had the opportunity, and forwarded those to Clinton's staff the day before he arrived. We also tried to include plenty of coping information -- where to call for tickets, what could be brought to the site, etc.

For our main story the day before Clinton's arrival, we contacted some of the people who had asked Clinton questions during his '93 visit -- a visit in which he talked about accountability -- to find out what they thought of the job the president has been doing since then. Because of the timeliness (Clinton arrived in Chillicothe at 8:05 p.m.) and newsworthiness of the visit, we published a morning edition rather than an afternoon edition for that Monday.

During the general election in 2000 the Gore campaign spent $\$ 10.7$ million on candidate travel, yet they did not base this expenditure on any quantifiable data. They, like other campaigns before and after, simply "know" that candidate visits to targeted areas have a positive effect on voters. Why? Candidate visits serve to motivate the base, recruit volunteers, generate enthusiasm, and produce sustained positive local press coverage. They also allow the candidate to connect with voters, raise money, and communicate their message.

At the campaign managers conference sponsored by the Institute of Politics and held at Harvard's Kennedy School of Government in 2001, Karl Rove, the Bush strategist, made to observations about campaign stops (Institute of Politics, 2002). Asked if he could do anything different in 2000 what would it be, Rove answered that he would have gotten a faster plane -- a metaphor for making more campaign stops. Second, when asked what he thought was the best tactical move the Gore campaign made? He responded that he thought it was the Mississippi River Trip after the Democratic Convention. He went on to say that it was good because it got the candidate "glowing news coverage in some relatively inaccessible areas of eastern Iowa, and other key battle ground states." He did not say that ad buys in this or that place should have been increased or decreased. He did not say that message could have been tweaked. He talked the Mississippi River Trip and the importance of other local campaign events.

In the last six weeks of the 2000 campaign, Al Gore spent a total of 4 nights out of 34 at his home at the Naval Observatory in Washington DC. For 3 of the 4 nights at home, he had day trips to Wisconsin, Iowa, and Michigan. Why this tremendous investment in time campaigning? While researchers have spent a considerable amount of time and effort on focus groups, and the effects of advertising, mail drops, door knocking, parental preferences, and phone banks, the effects of candidate appearances - and their impact on local media - need to be better understood. 


\section{Moving Voters along the Mississippi River}

Local visits move poll numbers for candidates, though the evidence on this is often difficult to disentangle because television advertisements are typically bought for the same period. Table 1 shows state visits by Vice President Gore and Governor Bush from October 18, 2000 through Election Day, November 7. Statelevel polling data can be especially useful in the closing days of a campaign when only a few swing states are in play (Franklin 2002). And using state-level polling data provided by Charles Franklin, we calculated, whenever possible, the Bush and Gore advantages in polls one week prior to a state visit and one week after a state visit. The boost from these visits averaged 1.56 percentage points for Bush and 1.40 percentages points for Gore.

\section{Table 1 About Here}

The state-level results from the last few weeks of the campaign are instructive, and small percentage point swings in key states may well have made all the difference in the campaign. However, state-level analysis fails to capture the kind of boost in visibility that candidates can get from local visits and friendly small-market media outlets. President Clinton's visits to places like Chillicothe, Ohio were very much on the minds of Vice President Gore's campaign staff.

With the 1992 and 1996 successes as the backdrop, the 2000 Gore Campaign held a series of meetings to discuss what could be done to break out double-digit losses to George Bush in early August public opinion polls. The campaign was looking for something that would have a serious electoral effect. Media consultants, Bob Shrum and Carter Eskew joined a campaign leadership team consisting of Tad Devine, Chris Lehane, Mark Fabiani, David
Morehouse, Jim Loftus, and Sam Myers. They gathered to decide what "bold strike" the campaign could unleash.

Tad Devine was, among other things, in charge of allocating resources to the various competing entities within the campaign (administration, advertising, travel, field operations, grass roots organizing, etc.). Knowing that the Bush campaign had a significant money advantage made any strategic or tactical decision involving money that much more important. For the Gore campaign, there was not much room for error. In budgeting, Devine said, "No one got everything they wanted as far as money is concerned, but each ultimately got what they needed."

During the discussion, Morehouse, Loftus, and Myers made a case for a Mississippi River boat trip. They laid out the plan that would, in effect, be the bold plan the campaign was looking for. The plan called for Al Gore, Tipper Gore, and the newly named Vice Presidential nominee, Senator Joseph Lieberman and his wife Hadassah, to embark on a riverboat trip immediately after the convention. The trip would take place on what was described as the "spine of America," the Mississippi River.

The trip was designed as a means of generating the visual images that the campaign was looking for and creating enthusiasm and positive press coverage in several targeted states. As part of the message development and targeting strategy, it was agreed that the trip would start in $\mathrm{La}$ Crosse, WI and travel through eastern Iowa, Western Illinois, and Missouri. Picking up small-town local media coverage as well as coverage from the Milwaukee, DesMoines, Chicago, and St. Louis media markets.

As Karl Rove stated, the trip generated glowing local press coverage and allowed Gore and Lieberman to travel to relatively remote, but important stops in key states. Stops along the way were planned for La Crosse and Prairie Du Chien, 
Wisconsin on August 18, 2000, Dubuque, Bellevue and Clinton, Iowa on August 19, Moline, Illinois on August 20 as well as Muscatine, Burlington and Keokuk, Iowa on the same day. The trip concluded with stops in Quincy, Illinois and Hannibal, Missouri on August 21.

The cost of the entire trip was roughly, $\$ 600,000$. Paid media penetration would have cost several million dollars for the same level of media exposure within those same markets. The trip also facilitated paid media for weeks after the trip ended. By using the trip as a stage from which to shoot campaign ads, the Gore campaign was able to prolong the sense of enthusiasm that the convention produced more than three weeks after it happened, rather than the two days Gore spent at the convention.

The reaction of local media in Prairie

Du Chien, Wisconsin was much like that generated by President Clinton's visit to Chillicothe, Ohio four years earlier. The Courier Press began blanket coverage of the visit from the moment it was announced. "If all goes well," reported the Courier Press on August 14, 2000, "and the timing is right, the Mississippi Blackhawk Water Ski Show Team will be leading the Mark Twain Riverboat with Al and Tipper Gore on board as they approach Lawler Park Friday night." As described in the August 22, 2000 Courier Press, Thousands enthusiastically gathered at Lawler Park Friday evening to greet Al and Tipper Gore. The Mark Twain Riverboat docked at 7:50 p.m. to the cheers of the crowd while 'Take Me to the River' sounded from large speakers. Al and Tipper Gore stepped onto stage while "Hometown" by John Cougar Mellencamp played. The Gores followed short speeches by Attorney General James Doyle and Congressman Ron Kind.... Following the 15-minute speech, Gore spent more than a half hour shaking hands with the crowd. He also met the ski team, and received a Mississippi Blackhawk windbreaker."
One would expect such enthusiastic - and sustained - local media attention to move voters closer to Gore, but the impact of local visits has traditionally been difficult to gauge. Internal Gore campaign polling, kindly provided here by campaign strategist Harrison Hickman maps the impact of the Mississippi River Trip in several local media markets. (The data for Illinois are based on regions, not media markets per se.) Polls were taken in late July 2000, during the river trip in August and again in September. Polls in areas that were visited during the trip are highlighted in bold in Table 2 .

Table 2 About Here

Contrasted with state-level polls, the results in Table 2 give us a much clearer look at the impact of campaign visits. The La Crosse and Eau Clair, Wisconsin media market is fairly well encapsulated, separate from the Madison and Wausau markets. In 2000, there were 153,630 Wisconsin homes and 23,860 Minnesota homes in the La Crosse market. Polls there in late July had Gore trailing Bush 41 percent to 34 percent, with 24 percent of the voters undecided. In the wake of the Mississippi River Trip, Gore led Bush by 13 percentage points, and the number of undecided voters was nearly cut in half. Prairie du Chien is in Crawford County, Wisconsin, and in November Gore won the 57 percent of the vote. Four years earlier, with Ross Perot also in the race, President Clinton received just under 52 percent in the county. In the cities of $\mathrm{La}$ Crosse and Prairie du Chien, Gore handily won every ward.

The impact on Gore's support found in the La Crosse media market was repeated all the way down the river. Within the four locally polled areas visited during the trip, Gore's net gain was 11.25 percentage points. Notably, the "undecided voters" fell 9.5 percentage points. That kind of a drop in undecideds over less than a month is virtually unknown in modern presidential 
campaigns. Elsewhere in the same states, Gore's net support dropped slightly, by a half of a percentage point and the undecideds fell just 3.3 percent. The Mississippi River Trip played well locally, but it also made news nationally. Every network covered the trip, and the tone of the coverage was captured by a Christian Science Monitor article on August 21, 2000 headlined "For Gore, Finally, Momentum Arrives."

In the areas visited by Vice President Gore, the effects of the river trip lingered well into September. His net gain over Bush in those media markets rose 11.25 percent in August to 16.5 percent by September. There appears to have been a strong friends-andneighbors effect that was not counteracted by heavy Bush campaign spending on television advertisements in those same markets.

While the polling discussed above was commissioned by the Gore campaign, the numbers were not reviewed until well after the November elections. There was casual talk that the Mississippi River Trip helped "win" Wisconsin and Iowa, but, as shown in Table 1, Governor Bush and Vice President Gore made several trips, and according to Goldstein (2004) spent a lot of money on television in those two states in the closing days of the campaign. Gore bought more advertising in Wisconsin than Bush did in those closing days, but the two were about even in Iowa.

The polling numbers in Iowa and Wisconsin, combined with the numbers of households in the various media markets, suggest that the Mississippi River Trip was, indeed, crucial to Gore's successes in both states. Consider Table 3, which shows the number of households in the Iowa media markets as of 2000 .

\section{Table 3 About Here}

Assume for simplicity that one person voted for either Bush or Gore from each household. Then multiply the increase from July to September in the Gore polls in each area following the Mississippi River Trip. (The Quincy market is tracked in Table 2 under the "Downstate North" polls). To be conservative in our estimates, we also assume that once Election Day came, the effect of the Mississippi River Trip was just half of that found in the September polls. Under these conditions, the trip generated 6,004 votes in the Cedar Rapids media market, 7,859 in the Quad Cities area, and 2,468 in the Quincy market. That is a total of 16,331 votes - or about four times the actual vote difference of 4,114 on Election Day. Gore won in Iowa 638,517 to 634,373. A similar analysis of media markets in Wisconsin, which Gore won by 5,708 votes, also suggests the pivotal importance of those mid-August local visits.

After the success of the Mississippi River Trip, the campaign explored three other potential river excursions. One, along the Ohio River going through Pennsylvania, Ohio, West Virginia, and Kentucky, another along the lower Mississippi River through Tennessee, Arkansas, and Louisiana, and finally one along the inter-coastal waterway in Southeastern Florida. Again, the idea was to travel through targeted battleground states generating sustained positive local news coverage and providing a metaphoric backdrop of campaigning along the nations waterways stopping in river towns along the way.

The Ohio River trip was not pursued mainly because the campaign made a strategic decision not to continue to pour resources into Ohio and to take Ohio off of its list of states to target (However, even without Ohio, the trip still would have gone through Western Pennsylvania and West Virginia, two very important regions for the campaign). In Florida, the campaign sent Jim Loftus, Director of Advance, to scout possible routes along the waterways there. He came back with a plan to travel through 
West Palm Beach County, Broward County, and Dade County.

Ultimately, a decision was made not to do any additional river trips. The relatively high travel cost, combined with the amount of time spent meandering along the rivers between stops, were two of the reasons the campaign did not pursue these tactics. However, the main reason was resource allocation. The general consensus at the time was simply that money was better spent on paid advertising. That general consensus, however, was not informed by any close look at the polling numbers nor clear sense for how many news cycles could be dominated by local coverage.

Given the money disadvantage the Gore campaign had in comparison with the Bush campaign, there was no room to maneuver when trying to match ad buys, dollar for dollar, in the targeted markets. Despite the near unanimous anecdotal evidence that the boat trip generated both the positive press coverage and the energy the campaign was looking for, the collective mind set of the campaign defaulted to the accepted means for moving voters - paid advertising.

Looking back, in a race as close as 2000 proved to be, there are any number of individual strategic and tactical decisions that, in retrospect, could have tilted the outcome in Vice President Gore's favor. Would another river trip through Tennessee, Louisiana, or Kentucky have moved enough voters to give those states to Gore? Probably not. Would another trip through Ohio, Arkansas, or West Virginia have given Gore an advantage? Maybe. Would a trip in Florida, through 3 of the 4 counties that ultimately became recount counties have given Gore the additional 537 votes he needed to win the state? Most likely so.

\section{Discussion}

In the wake of the 2000 presidential elections, Karl Rove resolved to build the
Republican Party's grassroots get-out-thevote efforts. The key to that strategy involved local presidential visits, timed to bring out the party faithful and to attract local media coverage. To that end, President Bush campaigned on behalf of Members of Congress in the months leading up to the 2002 off-year elections. In one year, he made six low-visibility campaign trips to Georgia on behalf of would-be Senator Saxby Chambliss. By flying into Georgia after dinner and leaving by midnight, President Bush avoided the national media and gathered local press coverage (Carney \& Dickerson 2002). Even his daytime visits to Georgia, however, such as an October 17, 2002 luncheon for Chambliss, were covered exclusively by the local press.

In his first fourteen months in office, President Bush made more local campaign trips on behalf of congressional candidates than President Clinton had during his full first term. Flying out of Washington, DC after the national media had compiled the nightly television news, President Bush tended to get strong local news coverage for his visits without generating much national interest in his activities. In those first 14 months, President Bush attended fundraisers that netted Republican congressional candidates $\$ 66.8$ million dollars. Doug Sosnick, who served as political director in Clinton's White House said of the Bush organization, "They're far more organized, far more disciplined and far more political than we were. And they're smart enough not to talk about it" (Keen 2002).

Of course, it is much easier to travel among local media markets when one is on Air Force One than when one is struggling for attention in a presidential campaign. As campaigns move into general election mode, television - not local visits and local media - has been king. Recall that the ratio of money spent on television ads versus travel in the 2000 Gore general election campaign was 4.14 to 1 . We suspect that would be far 
too high for any primary campaign. Candidates in general elections may be too quick to abandon the kinds of vote-getting techniques they used in during the caucuses and primaries. The Iowa caucuses and the New Hampshire primaries are all about local visits and local media. Money is spent on television advertisements, but these campaigns are won and lost by the strength of "troops on the ground." Yet after the party conventions, candidates tend to run national campaigns, largely through television ads.

Presidential campaigns are not truly national events, though. In 2004, perhaps no more than 15 states will be up for grabs, including: Arizona, Florida, Iowa, Maine, Michigan, Minnesota, Missouri, Nevada, New Hampshire, New Mexico, Ohio, Oregon, Pennsylvania, West Virginia and Wisconsin (Seelye 2003). Soon after the 2000 election, President Bush began focusing his trips to go through those states. In his first two years in office, President Bush visited Ohio, for example, every 9 weeks on average (Riechmann 2003). On December 4, 2003 when President Bush announced and end to U.S. steel tariffs, he did so while making his $23^{\text {rd }}$ visit to Pennsylvania - the most visits to any state in which the president did not also have a home (DeCoursey 2003).

As the 2004 presidential campaign heats up in the wake of the Democrat and Republican conventions, television advertisements will again seem pervasive especially in those few states that will actually be up for grabs. With that air war, well-funded on both sides, filling networks, we suspect to see both candidates "moving voters," not just "reaching voters" though sustained small-market campaign visits in key states. For far less than the costs of a national advertising Vice President Gore moved voters to his side with the August 2002 Mississippi River Trip. Those voters in Hannibal and La Crosse and Muscatine were critical voters in key states. The lessons of Mississippi River journey have not been lost on campaign operatives in either political party.

Ansolabehere, Stephen, \& Shanto Iyengar. 1995. Going Negative: How Political Ads Shrink and Polarize the Electorate. New York: Free Press.

Campbell, James. 2000. The American Campaign. College Station: Texas A\&M Press.

Carney, James \& John F. Dickerson. 2002. "W. and the 'Boy Genius'." Time, November 9, 2002.

DeCoursey, Peter L. “Tariff's End will Hit State Hard." The Patriot News. December 5, 2003.

Finkel, Steven. 1993. "Re-examining the Minimal Effects Model in Recent Presidential Campaigns." Journal of Politics 55:1-21.

Franklin, Charles H. 2002. "Pre-Election Polls in Nation and State: A Dynamic Bayesian Hierarchical Model.” Typescript. University of Wisconsin.

Freedman, Paul, \& Ken Goldstein. 1999. "Measuring Media Exposure and the Effects of Negative Campaign Ads." American Journal of Political Science, 43(4):1189-1208.

Friedrichs, Ryan. 2003. "Mobilizing 18-35 Year Old Voters: An Analysis of the Michigan Democratic Party's 2002 Youth Coordinated Campaign.” Typescript, Harvard University.

Gerber, Alan S., and Donald P. Green. 2000a. "The Effect of a Nonpartisan Get-Out-The-Vote Drive: An Experimental Study of Leafleting." The Journal of Politics 62:3, pp. 846-857, August 2000.

Gerber, Alan S. and Donald P. Green. 2000b. "The Effects of Canvassing, Telephone Calls, and Direct Mail on Voter Turnout: A Field Experiment." American Political Science Review. Volume 94, Number 3, September 2000.

Gerber, Alan S., and Donald P. Green. 2001a. "Do Phone Calls Increase Voter Turnout? A 
Field Experiment." Public Opinion Quarterly 65, pp. 75-85, 2001.

Gerber, Alan S., and Donald P. Green. 2001b. "Getting Out the Youth Vote: Results from Randomized Field Experiments." Unpublished report to the Pew Charitable Trusts and Yale University's Institute for Social and Policy Studies, December 29, 2001.

Gerber, Alan S., and Donald P. Green. 2003. "Mobilizing African Americans Using Mail and Commercial Phone Banks: A Field Experiment." Unpublished report, ISPS, Yale University, January 22003.

Gerber, Alan S., Donald P. Green and David W. Nickerson. 2003. "Getting Out the Youth Vote in Local Elections: Results from Six Door-to-Door Canvassing Experiments." Journal of Politics. 64(4):1083-96.

Goldstein, Ken. 2004. "What Did They See and When Did They See It?" in The Medium and the Message, Ken Goldstein and Patty Strach, ed., Prentice Hall. Upper Saddle River, NJ.

Holbrook, Thomas M. 1996. Do Campaigns Matter?, Thousand Oaks, CA: Sage Publications.

Holbrook, Thomas M. 2002. "Did the Whistle-Stop Matter?", PS: Political Science, March 2002: 59-66.

Institute of Politics. 2002. Campaign for President: The Managers Look at 2000. Hollis, NH: Hollis Publishing.

Jones, Jeffrey M. 1998. "Does Bringing out the Candidate Bring out the Votes?" American Politics Quarterly 26 (4): 395-419.

Joslyn, Mark R., \& Steve Ceccoli. 1996.

"Attentiveness to Television News and Opinion Change in the Fall 1992

Presidential Campaign. Political Behavior, 18(2):141-170.

Just, Marion R., Ann N. Crigler, Dean E. Alger, Timothy e. Cook, Montague Kern, Darrell M. West. 1996. Crosstalk: Citizens, Candidates and the Media in a Presidential Campaign. Chicago: University of Chicago Press.
Keen, Judy. 2002. "Bush Isn't on the Ballot, but his Influence Is.” USA Today. April 28, 2002.

News Watch. 2000. Gannet News Service. Comments on the Internet at http://update.usatoday.com/go/newswatch/9 6/nw0908-3.htm

Pew Research Center for the People and the Press. 2003. "November 2002 Campaign and Internet," Poll, October 30-November 24, 2002. Released January 5, 2003.

Riechmann, Deb. 2003. "Between fund-raisers, Bush visits Ohio factory." Associated Press National Wire. October 30, 2003.

Seelye, Katharine Q. 2003. "Shifts in States May Give Bush Electoral Edge." New York Times. December 2, 2003.

Shaw, Daron. 1999a. "The Effect of TV Ads and Candidate Appearances on Statewide Presidential Votes, 1988-1996." American Political Science Review. 93:345-61.

Shaw, Daron. 199b. "A Study of Presidential Campaign Event Effects from 1952 to 1992." Journal of Politics 61(2):387-422.

Vavreck, Lynn, Constantine J. Spiliotes, \& Linda L. Fowler. "The Effects of Retail Politics in the New Hampshire Primary." American Journal of Political Science, 46(3):595-610. 


\begin{tabular}{|c|c|c|c|c|c|c|c|c|c|c|c|c|c|c|c|c|c|c|c|c|c|}
\hline & \multicolumn{14}{|c|}{ October 2000} & \multicolumn{7}{|c|}{ November 2000} \\
\hline & 18 & 19 & 20 & 21 & 22 & 23 & 24 & 25 & 26 & 27 & 28 & 29 & 30 & 31 & 1 & 2 & 3 & 4 & 5 & 6 & 7 \\
\hline Bush & $\begin{array}{l}\text { WI } \\
\text { MI }\end{array}$ & $\begin{array}{l}\text { MI } \\
\text { NY }\end{array}$ & $\begin{array}{l}\mathrm{NH} \\
\mathrm{ME}\end{array}$ & & & $\begin{array}{l}\text { IA } \\
\text { WI }\end{array}$ & $\begin{array}{l}\text { IL } \\
\text { TN } \\
\text { FL }\end{array}$ & FL & $\begin{array}{l}\mathrm{PA} \\
\mathrm{OH}\end{array}$ & $\begin{array}{l}\text { MI } \\
\text { IN }\end{array}$ & $\begin{array}{l}\text { WI } \\
\text { MO }\end{array}$ & & $\begin{array}{l}\mathrm{NM} \\
\mathrm{CA}\end{array}$ & $\begin{array}{c}\text { CA } \\
\text { OR } \\
\text { WA }\end{array}$ & $\begin{array}{c}\text { MN } \\
\text { IA }\end{array}$ & $\begin{array}{c}\text { MO } \\
\text { IL } \\
\text { WI }\end{array}$ & $\begin{array}{c}\text { MI } \\
\text { WV }\end{array}$ & $\begin{array}{l}\text { MI } \\
\text { PA } \\
\text { NJ }\end{array}$ & FL & $\begin{array}{l}\text { TN } \\
\text { WI } \\
\text { IA } \\
\text { AR }\end{array}$ & $\mathrm{TX}$ \\
\hline Cheney & $\begin{array}{l}\text { PA } \\
\text { NJ }\end{array}$ & $\begin{array}{l}\text { WV } \\
\text { IL }\end{array}$ & $\begin{array}{l}\text { MN } \\
\text { WI } \\
\text { MI }\end{array}$ & MI & & & $\begin{array}{l}\text { WA } \\
\text { OR } \\
\text { NV }\end{array}$ & $\begin{array}{l}\text { NM } \\
\text { LA }\end{array}$ & $\begin{array}{l}\mathrm{TN} \\
\mathrm{OH}\end{array}$ & $\begin{array}{l}\text { WV } \\
\text { PA }\end{array}$ & $\begin{array}{l}\text { WI } \\
\text { IA }\end{array}$ & & $\begin{array}{c}\text { MN } \\
\text { IA } \\
\text { IL }\end{array}$ & $\begin{array}{l}\text { MO } \\
\text { AR } \\
\text { LA }\end{array}$ & FL & $\begin{array}{l}\text { TX } \\
\text { IL } \\
\text { PA }\end{array}$ & $\begin{array}{l}\mathrm{PA} \\
\mathrm{NH} \\
\mathrm{ME}\end{array}$ & $\begin{array}{c}\text { MI } \\
\text { WI } \\
\text { NM } \\
\end{array}$ & $\begin{array}{l}\text { CA } \\
\text { NV }\end{array}$ & $\begin{array}{l}\mathrm{NV} \\
\text { OR } \\
\text { WA }\end{array}$ & WY \\
\hline Gore & $\begin{array}{c}\text { MO } \\
\text { IA } \\
\text { MI }\end{array}$ & NY & $\begin{array}{l}\text { NY } \\
\text { MO } \\
\text { LA }\end{array}$ & PA & $\begin{array}{c}\text { TX } \\
\text { NM } \\
\text { OR }\end{array}$ & WA & $\begin{array}{l}\text { AR } \\
\text { LA } \\
\text { TN }\end{array}$ & $\begin{array}{l}\mathrm{TN} \\
\mathrm{MO}\end{array}$ & $\begin{array}{l}\text { IA } \\
\text { WI }\end{array}$ & $\begin{array}{l}\text { WV } \\
\text { PA }\end{array}$ & $\begin{array}{l}\text { PA } \\
\text { MN }\end{array}$ & MI & $\begin{array}{l}\text { MI } \\
\text { WI }\end{array}$ & $\begin{array}{l}\text { OR } \\
\text { CA }\end{array}$ & $\begin{array}{l}\text { FL } \\
\text { PA }\end{array}$ & $\begin{array}{c}\text { PA } \\
\text { IL } \\
\text { NM }\end{array}$ & $\begin{array}{c}\text { MO } \\
\text { IA } \\
\text { TN }\end{array}$ & $\begin{array}{c}\text { TN } \\
\text { WV } \\
\text { PA }\end{array}$ & $\begin{array}{l}\text { PA } \\
\text { MI } \\
\text { WI }\end{array}$ & $\begin{array}{c}\text { IA } \\
\text { MO } \\
\text { MI } \\
\text { FL }\end{array}$ & $\begin{array}{l}\text { FL } \\
\text { TN }\end{array}$ \\
\hline Lieberman & $\begin{array}{c}\text { WI } \\
\text { MD } \\
\text { NY } \\
\text { NJ }\end{array}$ & $\begin{array}{l}\text { NY } \\
\text { NJ }\end{array}$ & PA & & PA & FL & $\begin{array}{l}\text { TN } \\
\text { IN }\end{array}$ & $\mathrm{TN}$ & $\begin{array}{l}\mathrm{NM} \\
\mathrm{NV}\end{array}$ & WA & & MI & WI & $\begin{array}{c}\text { ME } \\
\text { NH } \\
\text { FL }\end{array}$ & $\begin{array}{l}\text { FL } \\
\text { AR }\end{array}$ & $\begin{array}{c}\text { MO } \\
\text { WI } \\
\text { MN } \\
\text { PA }\end{array}$ & FL & $\begin{array}{l}\text { FL } \\
\text { AR }\end{array}$ & $\begin{array}{l}\text { NM } \\
\text { NV } \\
\text { OR } \\
\text { WA }\end{array}$ & $\begin{array}{l}\text { MN } \\
\text { WI } \\
\text { ME } \\
\text { NH } \\
\text { PA }\end{array}$ & FL \\
\hline
\end{tabular}


Table 2

Gore Campaign Internal Polling Around Mississippi River Trip

\begin{tabular}{|c|c|c|c|c|c|c|c|c|c|c|c|c|}
\hline & Gore & Bush & $\begin{array}{l}\text { Other/ } \\
\text { Und. }\end{array}$ & $\begin{array}{l}\text { Net } \\
\text { Gore }\end{array}$ & Gore & Bush & $\begin{array}{l}\text { Other/ } \\
\text { Und. }\end{array}$ & $\begin{array}{l}\text { Net } \\
\text { Gore }\end{array}$ & Gore & Bush & $\begin{array}{l}\text { Other/ } \\
\text { Und }\end{array}$ & $\begin{array}{l}\text { Net } \\
\text { Gore }\end{array}$ \\
\hline Iowa Media Markets & \multicolumn{4}{|c|}{ July 22-25 } & \multicolumn{4}{|c|}{ August 19-23 } & \multicolumn{4}{|c|}{ September 5-8 } \\
\hline Des Moines & 45 & 40 & 14 & 5 & 46 & 46 & 8 & 0 & 49 & 41 & 10 & 8 \\
\hline Cedar Rapids & 45 & 36 & 19 & 9 & 51 & 40 & 9 & 11 & 49 & 36 & 15 & 13 \\
\hline Quad Cities & 31 & 44 & 25 & -13 & 41 & 47 & 12 & -6 & 41 & 43 & 16 & -2 \\
\hline Sioux City & 37 & 43 & 20 & -6 & 35 & 52 & 14 & -17 & 37 & 44 & 19 & -7 \\
\hline Other & 42 & 43 & 15 & -1 & 47 & 40 & 13 & 7 & 39 & 49 & 12 & -10 \\
\hline Illinois Regions & \multicolumn{4}{|c|}{ July $27-30$} & \multicolumn{4}{|c|}{ August 19-23 } & \multicolumn{4}{|c|}{ September $10-12$} \\
\hline Chicago & 60 & 32 & 9 & 28 & 63 & 30 & 7 & 33 & 59 & 27 & 13 & 32 \\
\hline Other Cook Co & 50 & 44 & 6 & 6 & 48 & 40 & 11 & 8 & 51 & 39 & 10 & 12 \\
\hline Chicago Suburbs & 39 & 51 & 10 & -12 & 40 & 46 & 15 & -6 & 38 & 51 & 11 & -13 \\
\hline Downstate No. & 41 & 45 & 14 & -4 & 51 & 39 & 10 & 12 & 60 & 31 & 9 & 29 \\
\hline Downstate So. & 47 & 40 & 13 & 7 & 43 & 45 & 13 & -2 & 48 & 45 & 7 & 3 \\
\hline Wisconsin Media Markets & \multicolumn{4}{|c|}{ July $22-25$} & \multicolumn{4}{|c|}{ August 21-24 } & \multicolumn{4}{|c|}{ September 5-8 } \\
\hline Milwaukee & 36 & 46 & 18 & -10 & 43 & 45 & 12 & -2 & 46 & 42 & 12 & 4 \\
\hline Green Bay & 36 & 46 & 19 & -10 & 44 & 51 & 6 & -7 & 45 & 42 & 14 & 3 \\
\hline Wausau & 46 & 41 & 13 & 5 & 47 & 51 & 1 & -4 & 46 & 42 & 11 & 4 \\
\hline La Crosse & 34 & 41 & 24 & -7 & $\mathbf{5 0}$ & 37 & 13 & 13 & 46 & 39 & 15 & 7 \\
\hline Madison & 50 & 37 & 13 & 13 & 49 & 36 & 15 & 13 & 45 & 38 & 17 & 7 \\
\hline Other & 54 & 25 & 20 & 29 & 58 & 33 & 9 & 25 & 35 & 47 & 18 & -12 \\
\hline
\end{tabular}


Table 3

Iowa Media Markets, by Number of Households, 2000

\begin{tabular}{|r|c|c|}
\hline \multicolumn{1}{|c|}{ Market } & $\begin{array}{c}\text { Households } \\
(1,091,700 \text { total })\end{array}$ & Percentage \\
\hline Cedar Rapids-Waterloo \& Dubuque & $\mathbf{3 0 0 , 2 0 0}$ & $\mathbf{2 7 . 5 0 \%}$ \\
\hline Davenport - Rock Island - Moline & $\mathbf{1 3 0 , 9 9 0}$ & $\mathbf{1 2 . 0 0 \%}$ \\
\hline Des Moines-Ames & 371,960 & $34.07 \%$ \\
\hline Mankato & 4,240 & $0.39 \%$ \\
\hline Omaha & 74,460 & $6.82 \%$ \\
\hline Ottumwa-Kirksville & 27,510 & $2.52 \%$ \\
\hline Quincy-Hannibal-Keokuk & $\mathbf{1 4 , 9 6 0}$ & $\mathbf{1 . 3 7 \%}$ \\
\hline Rochester-Mason City-Austin & 53,600 & $4.91 \%$ \\
\hline Sioux City & 106,880 & $9.79 \%$ \\
\hline Sioux Falls (Mitchell) & 6,900 & $0.63 \%$ \\
\hline
\end{tabular}

Source: LUC Media, Inc. http://www.lucmedia.com/mkst.html 